\title{
Detection of carbamyl phosphate synthetase 1 deficiency using duodenal biopsy samples
}

\author{
N J HOOGENRAAD, J D MITCHELL, N A DON, TERESA M SUTHERLAND, AND \\ A C MC LEAY \\ Department of Biochemistry, Latrobe University, Melbourne, and the Division of Gastroenterology, Prince of \\ Wales Children's Hospital, Sydney, Australia
}

SUMMARY The activity of urea cycle enzymes was assayed in duodenal biopsy specimens obtained from a female infant who presented with neonatal hyperammonaemia. All enzyme levels were normal except $\mathrm{N}$-acetyl glutamate-dependent carbamyl phosphate synthetase 1 (CPS1) which was half the mean activity in normal control specimens. A similar deficiency of CPS1 was also shown in duodenal specimens from the patients's mother who became slightly symptomatic after relatively high protein meals and during pregnancy, and had spontaneously modified her diet to one with protein restriction. The patient is growing normally on a dietary regimen similar to that spontaneously adopted by her mother. Urea cycle enzyme activity in the duodenal biopsy material from the controls was similar to that found in the normal human liver and appears to have distinct advantages as a means of assaying for urea cycle defects in patients with hyperammonaemia and their relatives.

Neonatal hyperammonaemia commonly results from deficiencies of urea cycle enzymes, with deficiency of the mitochondrial enzymes carbamyl phosphate synthetase 1 (CPS1) or ornithine transcarbamylase (OTC) present in severe cases. ${ }^{1}$ Urea cycle enzymes are generally assayed in liver, as few other tissues have been shown to contain adequate CPS1 and OTC activity for accurate assay. ${ }^{2}$ The potential danger in obtaining liver samples from severely ill infants with hyperammonaemia makes other detection methods desirable. Although analysis of blood and urine is useful in some cases, particular deficiences in arginosuccinate synthetase (citrullinaemia), arginosuccinate lyase (arginosuccinicaciduria), and arginase (argininaemia), it will not clearly identify CPS1 or OTC defects. Hyperornithinaemia and homocitrullinurea have been associated with CPS1 defects ${ }^{3}$ and oroticaciduria with OTC lesions ${ }^{4}$ but are not diagnostic for these enzyme defects. Demonstration of deficiencies in the activity of the component enzymes of the cycle remains the only unequivocal

Department of Biochemistry, Latrobe University, Melbourne, Australia

N J HOOGENRAAD, senior lecturer

TERESA M SUTHERLAND, NHMRC research assistant

Prince of Wales Children's Hospital, Sydney

J D MITCHELL, paediatric gastroenterologist

N A DON, visiting paediatrician

A C MC LEAY, visiting paediatrician diagnostic test. Measurement of urea cycle enzymes in leucocytes has been proposed. However, the method requires rather large samples of blood and even then gives disturbingly poor levels of CPS1 and OTC activity. ${ }^{5}$ We have found that duodenal mucosa contains sufficient levels of all urea cycle enzymes to enable accurate measurement of their activity in 5-10 mg gut biopsy specimens, and this paper describes the identification of 2 symptomatic carriers of an enzymatic defect in CPS1 by assay of duodenal biopsy specimens.

\section{Case report}

The patient, a girl, was the result of the first pregnancy of healthy, unrelated parents and was born at term after a normal delivery. The mother had been ill throughout pregnancy with abdominal pain and vomiting, which is now thought to be related to encouragement of the mother to maintain a high protein intake during her pregnancy (see below). The infant, whose birthweight was $3 \mathrm{~kg}$, developed generalised clonic convulsions on day 3 . Investigations at that time included lumbar puncture, serum electrolytes, calcium, magnesium, blood glucose, EEG, and urinary metabolic screen. The only abnormalities found while on breast feeding were hyperammonaemia and generalised aminoaciduria 
with plasma ammonia $135 \mu \mathrm{g} / \mathrm{ml} ; 7482 \mu \mathrm{mol} / 1$ (normal range 18-48 $\mu \mathrm{g} / \mathrm{ml}$; 998-2661 $\mu \mathrm{mol} / \mathrm{l}$ ) and a generalised increase in urinary amino-acids, particularly glycine. Urinary proline and glutamine were also raised with slight increase in ornithine. There was no change in the infant's convulsions after phenobarbitone, and IV diazepam and then phenytoin achieved only partial and temporary control. There was no apparent response to pyridoxine. After 48 hours of repetitive minor convulsions the infant was begun on oral glucose feeds and seizures stopped 12 hours later, only to reappear shortly after reinstituting breast feeding, which resulted in plasma ammonia rising to 100 $\mu \mathrm{g} / \mathrm{ml}(5543 \mu \mathrm{mol} / \mathrm{l})$. Convulsions again stopped within 6 hours of reinstituting glucose feeds. Low protein intake was instituted and on $0.86 \mathrm{~g}$ of protein $/ \mathrm{kg}$ per day her plasma ammonia was slightly raised at $57 \mu \mathrm{g} / \mathrm{ml}(3160 \mu \mathrm{mol} / \mathrm{l})$, with persisting increases in plasma glutamine and proline. The high fat and low protein intake during the first year produced pronounced obesity with some stunting of length.

Her growth pattern returned to normal after gradual increase in protein intake to $1 \cdot 2 \mathrm{~g} / \mathrm{kg}$ per day. Plasma ammonia remained marginally raised (65-71 $\mu \mathrm{g} / \mathrm{ml} ; 3603-3936 \mu \mathrm{mol} / \mathrm{l})$ with persisting high levels of glutamine, alanine, and glycine and marginally increased proline, ornithine, and aspartic acid. Serum aspartate amino transferase and galactose-1-phosphate uridyl transferase levels were normal both at 2 years and $4 \frac{1}{2}$ years. Prothrombin and kaolin clotting time were slightly prolonged in both the patient and mother before each bowel biopsy. These coagulation defects were responsive to parenteral administration of vitamin $\mathbf{K}$.

The child, now aged $4 \frac{1}{2}$ years, is a pleasant intelligent child who is growing normally. Her height $101.3 \mathrm{~cm}$ is on the 50th centile and weight $15.5 \mathrm{~kg}$ just below the 30th centile. Protein is included with every meal and she now drinks 100 to $200 \mathrm{ml}$ milk per day. Plasma ammonia on her present diet is $15 \mu \mathrm{g} / \mathrm{ml} ; 831 \mu \mathrm{mol} / 1$ (normal range 4-49 $\mu \mathrm{g} / \mathrm{ml}$; 222-2716 $\mu \mathrm{mol} / \mathrm{l})$.

The mother's history proved to be of much interest.
She had known for some years that if her protein intake was fairly high she was likely to become ill, vomit, and have abdominal pains during the next 24 to 36 hours. Of her own volition she has tended to restrict her protein intake, drinking little milk and eating very little red meat. A 2-week documentation of her typical eating pattern indicates an average intake of approximately $40 \mathrm{~g}$ protein per day $(0.7 \mathrm{~g} / \mathrm{kg})$, which is much lower than the typical protein intake for women in this country, which is estimated at $60 \mathrm{~g} /$ day.

\section{Methods}

Duodenal biopsies were obtained from the patient and her mother using a slightly modified standard technique. ${ }^{6}$ Biopsy samples were sealed in Parafilm and immediately frozen on dry ice and assayed for enzyme activity within 24 hours. Biopsy samples were obtained from the patient at 2 years of age ( 3 specimens) and again when she was 3.9 years (single specimen), at which time 3 specimens were also obtained from her mother. Standard histological assessment was carried out on some specimens: disaccharidase assays were performed to measure lactase, sucrase, and maltase by the method of Dahlqvist. ${ }^{7}$ Mucosal specimens (which varied in size from $6 \cdot 2$ to $27 \cdot 7 \mathrm{mg}$ ), were homogenised and assayed for CPS1 and OTC activity as previously described, ${ }^{8}$ except that CPS1 was measured by incubation for $10 \mathrm{~min}$ at $37^{\circ} \mathrm{C}$ and OTC for $5 \mathrm{~min}$ at $30^{\circ} \mathrm{C}$. Both methods are highly sensitive radiochemical procedures which enable CPS1 assays to be performed on as little as $1 \mathrm{mg}$ tissue $(0.1 \mathrm{ml}$ of $1.0 \%$ homogenate) and OTC assays on $100 \mu \mathrm{g}$ tissue $(0.1 \mathrm{ml}$ of $0.1 \%$ homogenate). Other urea enzymes were measured using the radiochemical methods of Schimke. ${ }^{9}$

\section{Results}

The urea cycle enzyme activities in the patient and the patient's mother were compared with normal controls (Table 1) and the level of activity of urea cycle enzymes in gut from controls was compared

Table 1 Urea cycle enzymes in gut* (nmol product formed per min/mg protein)

\begin{tabular}{|c|c|c|c|c|c|}
\hline Sample & CPSI & OTC & $\begin{array}{l}\text { Arginosuccinate } \\
\text { synthetase }\end{array}$ & $\begin{array}{l}\text { Arginosuccinate } \\
\text { lyase }\end{array}$ & Arginase \\
\hline $\begin{array}{l}\text { Patient } \\
2 \text { years } \\
3 \cdot 9 \text { years } \\
\text { Mother } \\
\text { Controls }\end{array}$ & $\begin{array}{l}0.68 \pm 0.44 \\
1.25 \\
1.14 \pm 0.06 \\
2.13 \pm 0.20\end{array}$ & $\begin{array}{c}101 \cdot 6 \pm 8 \cdot 0 \\
93 \cdot 3 \\
82 \cdot 4 \pm 7 \cdot 3 \\
100 \cdot 2 \pm 17 \cdot 3\end{array}$ & $\begin{array}{l}\text { ND } \\
146 \cdot 3 \\
142 \cdot 7 \pm 13 \cdot 6 \\
127 \cdot 7 \pm 10 \cdot 5\end{array}$ & $\begin{array}{l}\text { ND } \\
52.7 \\
63.9 \pm 13.5 \\
56.6 \pm 13.4\end{array}$ & $\begin{array}{l}\text { ND } \\
468 \\
442 \pm 40 \\
512 \pm 77 \cdot 1\end{array}$ \\
\hline
\end{tabular}

*Results from the patient at 2 years, the mother and controls are expressed as the mean $\pm \mathrm{SE}$ mean for three samples. ND $=$ not determined. 
Table 2 Comparison of urea cycle enzymes in gut and liver

\begin{tabular}{|c|c|c|c|c|c|}
\hline & CPSI & OTC & $\begin{array}{l}\text { Arginosuccinate } \\
\text { synthetase }\end{array}$ & $\begin{array}{l}\text { Arginosuccinate } \\
\text { lyase }\end{array}$ & Arginase \\
\hline $\begin{array}{l}\text { Gut } \\
\mathrm{nmol} / \mathrm{min} \text { per } \mathrm{mg} \text { protein } \\
\text { umol/min per } \mathrm{g} \text { fresh weight } \\
\text { Liver }\end{array}$ & $\begin{array}{l}2 \cdot 13 \pm 0.2 \\
0.12 \pm 0.04\end{array}$ & $\begin{array}{r}100 \cdot 2 \pm 17 \cdot 3 \\
5 \cdot 69 \pm 2 \cdot 55\end{array}$ & $\begin{array}{r}127.7 \pm 10.5 \\
7.25 \pm 0.60\end{array}$ & $\begin{array}{l}56.6 \pm 13.4 \\
3.22 \pm 0.76\end{array}$ & $\begin{array}{r}512 \pm 77 \cdot 1 \\
29 \cdot 1 \pm 7 \cdot 4\end{array}$ \\
\hline $\begin{array}{l}\mathrm{nmol} / \mathrm{min} \text { per } \mathrm{mg} \text { protein } \\
\mu \mathrm{mol} / \mathrm{min} \text { per } \mathrm{g} \text { fresh weight } \\
\text { Literature values* } \\
\mu \mathrm{mol} / \mathrm{min} \text { per } \mathrm{g} \text { fresh weight }\end{array}$ & $\begin{array}{l}3.65 \pm 0.81 \\
0.41 \pm 0.09 \\
0.6 \pm 0.9\end{array}$ & $\begin{aligned} 106 \cdot 3 & \pm 13 \cdot 4 \\
11 \cdot 8 & \pm 1 \cdot 5 \\
9-12 & \end{aligned}$ & $\begin{aligned} & 24 \cdot 5 \pm 8 \cdot 7 \\
& 2 \cdot 7 \pm 1 \cdot 0 \\
& 0 \cdot 5-1 \cdot 5\end{aligned}$ & $\begin{array}{l}18 \cdot 2 \pm 5 \cdot 6 \\
2 \cdot 0 \pm 0 \cdot 6 \\
\text { ND }\end{array}$ & $\begin{array}{l}3548 \pm 87 \\
394 \pm 9 \cdot 7 \\
230-800\end{array}$ \\
\hline
\end{tabular}

*Values for liver from Roerdink et al. ${ }^{19}$

with the level of activity normally found in the liver (Table 2). As shown, the patient had low levels of CPS1 on both occasions the enzyme was measured, the level being approximately half that found in the controls (Table 1). The level of CPS1 in the mother was similar to that of the patient and likewise showed about half normal activity.

Human duodenal mucosa was found to have high levels of all urea cycle enzymes (Table 2). Upper small intestine appeared to have about half the level of CPS1 activity found in the liver, whereas the OTC activity was comparable. The arginosuccinate synthetase and arginosuccinate lyase activities were much higher in the duodenum than in human liver, and arginase activities appeared to be lower. A portion of one specimen from the first procedure on the patient and also from the mother were shown to be histologically normal and contained normal levels of lactase, sucrase, and maltase.

\section{Discussion}

CPS1 deficiency is a fairly rare genetic defect. A study on 6 related subjects with the defect shows an autosomal recessive inheritance pattern. ${ }^{3}$ Although the findings on patients reported with this disorder vary, ${ }^{1}$ a common feature is hyperammonaemia associated with the intake of normal levels of protein, episodic motor impairment and seizures, and a generalised disturbance in amino-acid metabolism. The extent of CPS1 deficiency also varies considerably, and an almost complete lack of CPS1 has been reported in only one patient, who died at age 3 days. ${ }^{10}$ The 2 cases reported here show a less severe form of the defect, and the child, who was shown to be protein-intolerant had raised urine glycine levels, as did the patients of Freeman et al. ${ }^{11}$ and Gatfield et al., ${ }^{3}$ and raised urine ornithine, as in the cases reported by Gatfield et $a .^{3}$ The lack of a clear metabolic picture associated with this disease and the potential variability of the disorder makes it important to assay for the enzyme directly in tissue containing significant levels of CPS1. Although liver would appear a logical tissue for the measurement of urea cycle enzymes, patients with hyperammonaemia are poor candidates for liver biopsy procedures. ${ }^{12-14}$ Our study indicates that small intestinal biopsy samples are a suitable and probably more safely obtained source of tissue for assay of urea cycle enzymes. In addition, this technique is suitable for obtaining multiple samples which may lessen the chance of misleading results occurring as a consequence of lyonisation with sex-linked conditions such as OTC deficiency. Furthermore, as CPS1 is a highly labile enzyme, the activity in liver samples may be affected by compounds produced during the neonatal hepatitis which may accompany hyperammonaemia. Intestinal biopsies will avoid this complication, and the normality of the biopsy sample can readily be verified by histological analysis and disaccharidase assay. It should also be stressed that the early diagnosis of this disorder is important if intellectual impairment is to be avoided, since mental retardation is common in all the CPS1 defects reported to date,$^{13}$ and is apparently absent in the two cases reported in this paper.

Hyperammonaemia has been reported to be associated with defects in short-chain fatty acid metabolism, ${ }^{15-16}$ and we have found both CPS1 and OTC activities to be reduced in a patient with raised urine 3-methyl glutaric, 3-methyl glutaconic, and 3-hydroxy, 3-methyl glutaric acids (unpublished). Similarly, hyperammonaemia and CPS1 and OTC deficiencies may be associated with Reye's syndrome. ${ }^{17-18}$ However, these other causes of hyperammonaemia were ruled out since OTC was normal and only CPS1 was reduced in activity; this reduction being noted both during the hyperammonaemic crisis and on subsequent measurement when the patient was well. In addition, no abnormal urine organic acid pattern emerged on gas-liquid chromatography of urine.

An unusual finding in the present cases was the vitamin K-responsive coagulation defects observed in both the mother and daughter, when there was no other apparent evidence of disturbed hepatocyte 
function. This observation, which suggests a link between the CPS1 lesion and vitamin $\mathrm{K}$ metabolism, appears to warrant further exploration.

We thank Kathy Ewing for technical assistance and Maureen Rochester for preparation of the manuscript.

This work was supported by a grant from the National Health and Medical Research Council of Australia.

\section{References}

1 Hsia Y E. Inherited hyperammonemic syndromes. Gastroenterology 1974; 67: 347-74.

2 Jones M E, Anderson A D, Anderson C, Hodes S. Citrulline synthesis in rat tissues. Arch Biochem Biophys 1961; 95 : 499-507.

3 Gatfield P D, Taller E, Wolfe D M, Haust M D. Hyperornithinemia, hyperammonemia, and homocitrullinuria associated with decreased carbamyl phosphate synthetase 1 activity. Pediatr Res 1975; 9: 488-97.

4 Goldstein A S, Hoogenraad N J, Johnson J D, et al. Metabolic and genetic studies of a family with ornithine transcarbamylase deficiency. Pediatr Res 1974; 8: 5-12.

5 Wolfe D M, Gatfield P D. Leukocyte urea cycle enzymes in hyperammonemia. Pediatr Res 1975; 9: 531-5.

6 Townley R R W, Barnes G L. Intestinal biopsy in childhood. Arch Dis Child 1973; 48: 480-2.

7 Dahlquist A. Method for assay of intestinal disaccharidases. Anal Biochem 1964; 7: 18-25.

8 Sinatra F, Yoshida T, Applebaum M, Mason W, Hoogenraad N J, Sunshine P. Abnormalities of carbamyl phosphate synthetase and ornithine transcarbamylase in liver of patients with Reye's syndrome. Pediatr Res 1975; 9: 829-33.

9 Schimke R T. Micromethods for the assay of argininosuccinate synthetase, arginosuccinase, and arginase. In:
Tabor H, Tabor C W, eds (series eds Colowick S P, Kaplan $\mathrm{N}$ O). Methods in enzymology. Vol. 17A. Metabolism of amino acids and amines. New York: Academic Press, 1970: 324-9.

10 Gelehrter T D, Snodgrass P J. Lethal neonatal deficiency of carbamyl phosphate synthetase. N Engl J Med 1974; 290 : 430-3.

11 Freeman J M, Nicholson J F, Schimke R T, Rowland L P, Carter S. Congenital hyperammonemia: association with hyperglycinemia and decreased levels of carbamyl phosphate synthetase. Arch Neurol 1970; 23: 430-7.

12 Hopkins I J, Connely J F, Dawson A G, Hird F J, Maddison J. Hyperammonaemia due to ornithine transcarbamylase deficiency. Arch Dis Child 1969; 44: 143-8.

13 Nicholson J F, Freeman J M. Metabolism of compounds labelled with ${ }^{15} \mathrm{~N}$ by an infant with congenital hyperammonemia. Fediatr Res 1972; 6: 252-60.

14 Menghini G. One-second biopsy of the liver: problems of its clinical application. $N$ Engl J Med 1970; 283: 582-5.

15 Kang E S, Snodgrass P J, Gerald P S. Methylmalonyl coenzyme A racemase defect: another cause of methylmalonic aciduria. Pediatr Res 1972; 6: 875-9.

16 Landes R D, Avery G B, Walker F A, Hsia E. PropionylCo A carboxylase deficiency (propionic-acidemia): another cause of hyperammonemia (abstract). Pediatr Res 1972; 6: 394.

17 Brown T, Brown H, Lansky L, Hug G. Letter: Carbamyl phosphate synthetase and ornithine transcarbamylase in liver of Reye's syndrome. $N$ Engl J Med 1974; 291 : 797-8.

18 Brown T, Hug G, Bove K, Brown H, Lansky L. Reye's syndrome. Lancet $1974 ; 2: 716-7$.

19 Roerdink F H, Gouw W L M, Okken A, et al. Citrullinemia: report of a case with studies on antenatal diagnosis. Pediatr Res 1973; 7 : 863-9.

Correspondence to Dr John D Mitchell, Prince of Wales Children's Hospital, Randwick, New South Wales 2031, Australia.

Received 27 March 1979 